\title{
Commentary \\ Factor VII and the brain: time to get this research done!
}

Richard P Dutton

University of Maryland School of Medicine, R Adams Cowley Shock Trauma Center, University of Maryland Medical System, MA, USA

Corresponding author: Richard P Dutton, rdutton@umnet.umaryland.edu

Published: 31 August 2007

Critical Care 2007, 11:161 (doi:10.1186/cc6097)

This article is online at http://ccforum.com/content/11/4/161

(C) 2007 BioMed Central Ltd

See related research by Kluger et al., http://ccforum.com/content/11/4/R85

\begin{abstract}
Traumatic brain injury is the leading killer after trauma, in part because of coagulopathy. Factor VIla may be a useful therapy in this setting, depending on the relative risk for thromboembolic complications. Kluger and coworkers recently conducted a retrospective review of patients with traumatic brain injury from a previous factor VIla and trauma trial. It documents an encouragingly low rate of complications, and should provide a strong incentive to conduct a prospective study of factor Vlla in patients with severe traumatic brain injury.
\end{abstract}

Kluger and colleagues [1] have done us a service with their careful review of outcomes in patients with traumatic brain injury (TBI) from a previous factor VIla (FVIla) trauma trial. Although the numbers are small, this work will be important in motivating future prospective trials. Mortality in this small cohort was greater than in the overall study population, emphasizing the lethality of TBI plus shock. The lack of selfreported thromboembolic events is encouraging and is in accordance with other prospective trials of FVIla use, which have suggested that the risk is real but not excessive. Also encouraging are the trends in the outcome variables reported, including mortality and organ failure end-points. Although none of these are significant in themselves, they are collectively significant in that they all vary in the same way, favoring FVIla.

Traumatic brain injury (TBI) is the most common cause of death after trauma, and it is the most difficult to treat. With no ability to repair or replace injured brain tissue, we are reduced to management of symptoms as they develop and often futile efforts to prevent secondary injury from hypoxia, hypotension, hyperglycemia, hyperthermia, electrolyte imbalances, or progressive cerebral edema. This task is especially complex in the polytraumatized patient, because each associated injury - whether treated or ignored - adds to the likelihood of secondary TBI. Delayed fracture fixation increases the risk for pulmonary dysfunction, whereas early operative repair exposes the brain to the risks for hypotension, hypoxia, and adverse effects of anesthetic agents. The combination of hemorrhagic shock and severe TBI is especially lethal, with mortality as much as 10 times greater than that for either condition alone. Coagulopathy contributes a large part of this pathophysiology.

Severe TBI causes coagulopathy through a number of mechanical and inflammatory pathways, but the most significant of these is simple consumption. The brain is rich in tissue factor, which is exposed to the circulation in large quantities when the blood-brain barrier is disrupted by trauma. This leads to a coagulation defect through two mechanisms. First, the already small quantity of FVIla normally found in the circulation is quickly consumed. Second, this consumption triggers a strong local anticoagulant response, which can easily become a systemic effect. Prolonged prothrombin time is common following severe $\mathrm{TBI}$, even without evidence of systemic blood loss, and is a very strong marker for poor outcome.

Recombinant FVIla therapy for TBI has been enticing to clinicians for the past 5 years. In our own series of patients receiving FVIla following trauma - perhaps the largest single center experience in the world - TBI is the second leading indication, found in about 150 out of 350 patients [2]. There are several reasons for this anecdotal enthusiasm. The immediate clinical effect is dramatic and readily observed; the prothrombin time normalizes rapidly, even with small doses, and surface bleeding from wounds visibly slows. Emergency neurosurgical procedures are greatly facilitated, and transfusion requirement is reduced. We have also harbored the notion, unproven but physiologically sensible, that FVIla will slow the progression of TBI-associated intracranial hemorrhage on both the macroscopic and microscopic levels, and thus reduce the potential for secondary injury. To

$\mathrm{FVIla}=$ factor VIla; $\mathrm{TBI}=$ traumatic brain injury. 
the extent that hemorrhagic stroke and TBI have similar pathophysiology, early findings with use of FVIla in stroke patients have also been encouraging [3].

Tempering the use of FVIla in TBI patients has been the cost, the lack of clinical trials addressing this population, and most importantly - the unknown risk for thromboembolic complications. After retrospectively examining this risk in our own series of patients, we were struck by two things. First, the baseline rate of post-traumatic cerebral infarction is not well understood; retrospective diagnosis depends on the presence of computed tomography scans with contrast (unusual in $\mathrm{TBI}$ ) or computed tomography scans obtained days to weeks after injury (when infarcted brain can be identified), and also to some degree on the resolution of the scanner used. Second, the thromboembolic risk is closely linked to the anatomic injury itself [4]. All of the post-FVIla brain infarcts observed in our series occurred in the presence of severe TBI, just as the majority of all of the complications we found occurred at the site of an identified vascular injury.

The current worldwide trial of FVIla in trauma patients, focused on the treatment of hemorrhagic shock, specifically excludes patients with severe TBI. There is a clear and urgent need to study this population, however, and to study the very wide range of doses currently seeing anecdotal use, all the way from 10 to $15 \mu \mathrm{g} / \mathrm{kg}$ in centers such as my own to the $400 \mu \mathrm{g} / \mathrm{kg}$ reported on by Kluger and coworkers [1]. Even a modest improvement in long-term outcomes achieved by early treatment with FVIla would have an impact on the population of patients with severe TBI and give us a badly needed arrow for our therapeutic quiver.

\section{Competing interests}

RD has received research funding and consulting fees from Novo Nordisk, Inc, the manufacturers of FVIla and is a member of their international steering committee for trauma trials.

\section{References}

1. Kluger Y, Riou B, Rossaint R, Rizoli SB, Boffard KD, Choong PI, Warren $B$, Tillinger M: Safety of rFVila in hemodynamically unstable polytrauma patients with traumatic brain injury: post hoc analysis of $\mathbf{3 0}$ patients from a prospective, randomized, placebo-controlled, double-blind clinical trial. Crit Care 2007, 11:R85.

2. Dutton RP, Stein DM: The use of factor VIla in haemorrhagic shock and intracerebral bleeding. Injury 2006, 37:1172-1177.

3. Mayer SA, Brun NC, Begtrup K, Broderick J, Davis S, Diringer MN, Skolnick BE, Steiner T; Recombinant Activated Factor VII Intracerebral Hemorrhage Trial Investigators: Recombinant activated factor VII for acute intracerebral hemorrhage. $N$ Engl J Med 2005, 352:777-785.

4. Thomas GOR, Dutton RP, Hemlock B, Stein DM, Hyder M, ShereWolfe R, Hess JR, Scalea TM: Thromboembolic complications associated with FVIla administration. J Trauma 2007, 62:564569. 